\title{
Stylization of Commedia dell'arte in Latvian and Foreign Modernist Drama and Theatre: Methods and Sources
}

\author{
VIKTORIJA SLÜKA
}

\begin{abstract}
The chosen research subject - stylization of commedia dell'arte in Latvian and foreign Modernist drama and theatre - is a little studied theme in Latvian literary and theatre theory. Unrealistic representations (which are connected with theatricalization) are key features of modern drama which manifests each of the modernism movements in different ways. The most important of these that will be discussed are commedia dell' arte stylization in drama and theatre, theatricalization and the principle of theatre in theatre or play in play; balagan, life and art balaganization etc.

Commedia dell'arte stylization will be analyzed with examples from selected plays by Latvian authors who represent different types of drama - Ādolfs Alunāns, Rūdolfs Blaumanis, Elza Stērste, Austra Mētere-Ozoliņa and Valdemārs Dambergs. Theatricalization elements also are in Latvian authors' plays that belong to different modernism movements - Rainis, Jānis Jaunsudrabinš, Mārtiņš Ziverts, Edvards Vulfs, Linards Laicens, Leons Paegle, Kārlis Dziḷleja etc. Foreign authors in whose works one can analyze theatricalization include such dramatists as Luigi Pirandello, Frank Wedekind, August Strindberg, Morris Maeterlinck, Arthur Schnitzler, Federico Garcia Lorca, Alexander Block etc. One group of these foreign authors directly influenced Latvian dramatists, because their plays had been regularly staged in the Latvian theatres; while the second group influenced them partly because their aesthetics typologically coincide with the Latvian authors' aesthetics and aims.
\end{abstract}

Keywords: commedia dell'arte, stylization, theatricalization, theatrical theatre, balagan, modern drama, modernism

Importance of the stylization and theatricalization in the Age of Modernism

In the first half of the $20^{\text {th }}$ century different directors in European and Russian theatres attempted to create a theatrical theatre on the stage. The viewer is provoked and often remains in opposition to the actors, because he begins to doubt the truth of what he sees. One of the principle methods of creating theatrical theatre is using the commedia dell'arte elements (mask, buffoonery, improvisation, carnival, lazzi etc.); for example, in Vsevolod Meyerhold 
Stylization of Commedia dell'arte in Latvian and Foreign Modernist Drama and Theatre

(Всеволод Мейерхольа, 1874-1940), Alexandr Tairov (Алексанар Таиров, 1885-1950), Jacques Copeau (1879-1949), Max Reinhardt (1873-1943) and other theatre directors' productions.

Many $20^{\text {th }}$-century writers with stylization techniques in their plays began to portray the world as a theatre, which together with theatricalization not only in theatre but also in life, shows people as marionettes, where naturalness takes over from artificiality. People are represented as dummies, as constant masks (or types), which do not know psychological trials, feelings of love and obligation and are not related to any particular religion that often epitomizes infernal, metaphysical and mystical things; for example characters in the Russian writer Alexander Blok's (Алексанар Блок, 1880-1921) play Балаганчик (Balaganchik, 1906), Austrian - Arthur Schnitzler's (1862-1931) Marionetten (Marionettes, 1906), Italian - Luigi Pirandello's (1867-1936) Sei personaggi in cerca d'autore (Six Characters in Search of An Author, 1921), Enrico IV (Henry IV, 1922), Spain - Federico García Lorca’s (1898-1936) Así que pasen cinco años (When Five Years Pass, 1931) etc.

Modernism has an international nature, so in the first half of the $20^{\text {th }}$ century there were a number of artistic movements (that is, a diverse set of philosophical aesthetic views) that emerged in different countries, as well as national variants - that were subsumed into the broad designation modernism. Modernism is a certain type of artistic development, which is generally considered to have begun in the last decade of the nineteenth century. While it gradually declined in several Western European countries in the 1950s, due to political and social reasons, the modernist boom in Russia ended considerably earlier.

Before Modernism, the existing view was that the aim of art was to reflect the objective reality of life or its meaning. With Modernism this idea was pushed into the periphery, because the primary aspect was now the subjective representation of reality. Artists postulated themselves as demiurges, while their works of art presented personal impressions, reflections and emotional experiences of reality. An approximate fifty-year period of modernism ensued with many exciting, interesting, high-quality and artistically-rich works with contemporary ideas and many allusions. ${ }^{1}$ The predominance of stylization in Modernism accented artificiality, which replaced a realistic picture of life. Art started to become analyzed, critically assessed and self-aware.

1 Commedia dell'arte stylization is one of the features of modernist art. The period of $16^{\text {th }}$ century Italian theatre was the source of inspiration for writers (mostly poets, novelists and playwrights) and composers, painters and ballet dancers, as well as film directors and the silent film actors. 
SLŪKA

In the period of Modernism, the theatre was important in art. At the end of the nineteenth century and at the beginning of the twentieth century model constructions of artificial reality became very peculiar in the theatre (and hence in drama). Reality was modelled by theatrical rules. Theatricalization in Modernist art not only defined the culture of artistic style, but also its creators' (that is the artists') life style ${ }^{2}$. Many $20^{\text {th }}$-century writers in their plays represent the world as a model of the Masque Theatre. Theatricalization processes in life and in the theatre were very important for the development of Modernism.

\section{Stylization as a part of theatricalization}

It is important to describe stylization as a major literary and artistic movement, i.e. it is a complex synthetic concept, which includes various meanings of expressions and forms that constitute an aesthetic unity. Stylization, as a term, tends to be explained in different ways. Stylization in texts often appears when the writer has an original, independent plot. At the same time the expression is shaped by successive foreign texts or text groups which may include allusions.

Modernism made topical Friedrich Nietzsche's (1844-1900) statement Gott ist tot! (God is dead!). This new artist-modernist progressive focus was not only found in the commedia dell'arte, but also in theatrical genres such as mystery and farce (all of which are related to the aesthetics of the theatre) and irony (often in grotesque form which represents life as a game). In the period of Modernism the three genres mentioned above were stylized or restored in texts and theatrical performances.

Besides new forms of expression and innovative searching ways, modernists in their creative work show that recourse to primary sources (such as the gross theatrical forms) and stylization or restoration allows art to be renovated and encoded in new, contemporary philosophical and aesthetic concepts. Commedia dell'arte stylization is one of the modernist art - theatricalization features. In the period of modernism many writers and artists were intensively engaged with stylization.

In the first decades of the $20^{\text {th }}$ century the Western European and Russian theatres attempted to show theatrical theatre. Initially the idea was at the periphery, because realistic, naturalistic and psychological acting dominated in the theatre; productions were based on texts, which directly reflected everyday

2 For instance, Austrian poet, artist, playwright Oskar Kokoschka (1886-1980); Russian poet, musician, novelist Mikhail Kuzmin (Михаим Кузьмин, 1872-1936); Latvian actress, theatre director Anna Lācis, or Asja (1891-1979) etc. 
Stylization of Commedia dell'arte in Latvian and Foreign Modernist Drama and Theatre

life (Clayton 1993: 6). One of the most important features of the theatrical theatre, Symbolist Theatre, started in Paris at the end of the 1880s when André Antoine (1858-1942) began to develop Symbolist Theatre (Radzobe 2002: 40).

The main principles of Symbolist Theatre were stylization and esthetization, which were employed in all areas of theatrical performances - the actors' playing style, scene design, costumes, the manner of speech, stage movement, light and sound score. The major search directions of Symbolist Theatre were connected with earlier theatre renovation techniques which had been characterized by unrealistic forms of presenting life:

1) high interest in the puppet and puppet theatre,

2) re-animated Renaissance pantomime,

3) experimentation with a recitation, exploring the rhythm of poetry, synthesis of singing, recitation variations and their ability to influence the audience (a renewed classical theatre tradition),

4) increased interest in antique plots and stories, and in particular the antique forms of theatre games,

5) interest in medieval religious theatre - miracle, mystery, morality plays, as well as the medieval farces.

At the end of the $20^{\text {th }}$ century Symbolist Theatre "had prepared a rich philosophical and aesthetic luggage of ideas, which served as a theater stage direction which flourished in the $20^{\text {th }}$ century" (Radzobe 2002: 50). This theater highlighted contrasts between the real (audience) world and the unrealistic, mysterious world of symbols (the performance).

\section{Balagan and balaganization}

Connected to theatricalization is the balagan theme. To the modern artist the concept of balagan is very important, particularly in theater directing and drama. Balagan and commedia dell'arte themes and variations in foreign (not Latvian) and in fragments in Latvian drama can be compared, for example, to Blok's play Balaganshik and Schnitzler's trilogy Marionettes. Balagan traditions of different interpretations and variations are found in Western European and Russian modernist drama - Blok, Majakovsky, Schnitzler, Lorca, Pirandello, Brecht. Balagan in Russian modernist theater has a certain set of motifs and 
SLŪKA

themes. Balagan ${ }^{3}$ is a symbol of reform and even a metaphor. This phenomenon includes a multilayered historical memory, which includes a variety of not only Russian, but also of Western Europe traditions including commedia dell'arte.

J. Douglas Clayton writes that balagan in $20^{\text {th }}$-century art can be regarded as a universal genre. It is one of the most popular models combining low and high art. "Balagan is a correlation of two concepts - circus and commedia dell'arte. All three forms are characterized by the following elements: 1) an unrealistic nature of art, it is a game, or a notional theater form, 2) the performers play in a grotesque style, 3) wearing the masque.” (Clayton 1993: 232)

\section{The Birth of the Italian mask theater and the beginning of the commedia dell'arte stylization tradition}

Commedia dell'arte (comedy of professional players) appeared in Italy and developed in the second half of the $16^{\text {th }}$ century and was also popular in the first half of the $17^{\text {th }}$ century, the period of the most famous troupes. ${ }^{4}$ There were two commedia dell'atre centres - Venice and Naples - and thus two traditions: the northern or Venetian one and the southern or Napolitan one. Due to different dialects and geographical places there were different names of general and peripheral masks. The character types in commedia dell'arte can be divided into two general categories: the unmasked (the young lovers) and the masked (masters and servants). (Brockett, Hildy 1999: 145-147) During the above mentioned period, when commedia dell'arte was at the peak of its popularity, there appeared more than a hundred masks but it is important to add that many of them were modifications of the basic group of masks:

3 As an indication of the theme of modernist drama balagan can be a non-realistic play, puppets live as real people, primarily because the 'balgan' or specific stage forms (like the Ukrainian - vertep or Polish - shopka, Russian - balgan) where puppet theatre performances were often played.

4 "The commedia dell'arte continued until about 1775 , but never regained the prestige it commanded prior to 1650 . Although it was always most popular in Italy, France was a second home, and troupes often traveled in Spain, Germany, Austria, England, and elsewhere in Europe. Wherever they went, they influenced native actors and writers." (Brockett, Hildy 1999: 148) An interesting fact, the commedia dell'arte actors visited Riga in 1696 (Kundziņš 1968: 15). 
Stylization of Commedia dell'arte in Latvian and Foreign Modernist Drama and Theatre

Arlecchino (Harlequin), Truffaldino, Pedrolino ${ }^{5}$, Fantesca (or Servetta) ${ }^{6}$, Pulcinello, Capitano, Pantalono, Dottore etc. Italian comedy masks always had social connotations and could be divided not only on a geographical basis, but also according to their functional groups, namely lyrical masks, satirical masks and comic masks.

In Western Europe, the commedia dell'arte stylization tradition started in 1892 in Milan when Ruggero Leoncavallo (1857-1919) staged the opera Pagliacci. In this period there was also a great interest in the works of the Italian dramatists Carlo Gozzi (1720-1806) and Carlo Goldoni (1707-1793). Leoncavallo's opera incorporated the essence of commedia dell'arte seen through the lens of $19^{\text {th }}$-century romanticism in which Pagliaccio/Pierrot as a character (mask) is unable to distinguish life from the theater. The archetypal masks are not only transformed but they also represent new value in the old form. ${ }^{7}$ Behind Harlequin's mask hides a successful $20^{\text {th }}$-century man, behind Pierrot's mask a sensitive artist, while behind Columbine's mask - a pragmatic woman who is the catalyst between Harlequin and Pierrot. "Another early manifestation of the international interest in commedia dell'arte was König Harlekin (King Harlequin, 1900), by the Viennese playwright Rudolph Lothar (1865-1943). [...] This play was something of an international incident' because of its success on almost all European stages; it was also translated into different European languages." (Clayton 1993: 37-38) The theme of the play was multicultural and understandable to every European. J. D. Clayton points out that the play has some allusions to Shakespeares' Hamlet (1603). Lotar's play "bears only the outward trappings of commedia dell'arte - that is, the names of characters - but their presence is unmotivated, and the play has a unity of style that removes it from the tradition" (Clayton 1993: 39).

In different $20^{\text {th }}$-century texts these three masks and relationships between them often form a love triangle. The main Italian folk theater servants Pierrot, Harlequin and Columbine - in modernist drama have a different social status. The first character represents the sacrifice of life and the rejected lover, the second one is a brutal and cynical trickster who is the initiator of the

5 Pedrolino (also Pierino later known as Pierrot) is sentimental, sad, lonely, honest, and able to quickly fall in love, he is full of confidence and trust in his master. The Pedrolino mask is usually played by a young actor. During the formation of Italian folk theatre the Pedrolino mask has been on the periphery.

6 Later known as Colombina.

7 Commedia dell'arte in its historic homeland - Italy - in the $16^{\text {th }}$ and $17^{\text {th }}$ century was intended for mainly grassroot entertainment, but in modernist works it has become highbrow. 
SLŪKA

conflict, the third one - Pierrot's and Harlequin's love object. In modernist drama themes and other commedia dell'arte techniques stylization can be found. Also there may be indirect similarities where only by careful reading one can see allusions to the commedia dell'arte aesthetics. Clayton precisely indicates: "Commedia dell'arte was for the modernists what the folk-tale or ballad was for romantics. Hence, through the icons - Pierrot, Harlequin, and the rest - remain substantially the same, the sociocultural context is totally different from that sixteenth- and seventeenth-century Italy, for example." (Clayton 1993: 4)

\section{The best examples of commedia dell'arte stylization in Latvian drama}

At the beginning of the $20^{\text {th }}$ century one can find similarities between the Latvian author Rūdolfs Blaumanis' (1863-1908) comedies (or - as the author himself called them joku splèles or fun plays and scenes of life) and the $19^{\text {th- }}$ century Latvian dramatist and theater director Ādolfs Alunān's (1848-1912) drama, methods and sources.

In Alunān's and Blaumanis' plays some typological parallels with commedia dell'arte can be found. In other words, they often have a love plot and marriage theme, relationships between masters and servants, misunderstandings, etc. They are socially involved dramatic texts that are ably complemented by comic elements or episodes.

Love plots, misunderstandings and farces have been used in many earlier localizations $^{8}$ and plays for comic effect (for instance, the play Žūpu Bērtulis - the German Baltic writer Alexander Johann Stender's (1744-1819) version of the Danish and Norwegian writer Ludvig Holberg's (1684-1754) play Jeppe på bjerget eller den forvandlede Bonde (Jeppe of the Hill, or The Transformed Peasant, 1722)). In both Blaumanis' and Alunān's plays can be found features from German poses which are based on the elements of farce. Blaumanis' comedies are an organic continuation of the previous tradition of drama, but his texts are a new form of literature showing the psychological level and the degree of professionalism in Latvian drama. In the first half of the $20^{\text {th }}$ century fun play elements and scenes of life type comedies continue in the works of Latvian writers such as Edvards Vulfs and Valdemārs Dambergs.

8 Localization (Latvian lokalizejjums from French localiser) means that the translation is not literal, but is adapted to the country for which it is being translated and the conditions in which the people there live. This method was popular in $18^{\text {th }}$ - and $19^{\text {th }}$ century Latvian literature. 
Stylization of Commedia dell'arte in Latvian and Foreign Modernist Drama and Theatre

In Latvian literature Elza Stērste (1885-1976), writer Edvarts Virzas' (1886-1940) wife, is known as a writer of poetry and prose. She was closely connected with the theater. In her literary memories (Stērste 1985) she shares her impressions of childhood when she saw Alunān's performances and her father Andrejs Stērste ${ }^{9}$ playing on the stage.

There are theatricalization elements in Elza Stērste play Arlekinna kāzas (The Harlequin's Wedding, 1938). It is important to analyze the plot, main characters and play structure. In the centre of comedy are theatrical drama and people's destinies. This is one of the best examples of the commedia dell'arte style in Latvian modernist drama. Three acts with farce situations are structured by the principle of play in play that is one of the favorite $20^{\text {th }}$-century forms.

In the centre of Stērste's play Arlekina kāzas one can see a love triangle as in commedia dell'arte plays. The Latvian author's message is that human life is a theater, while the artists' life is theatrical theater. The writer's play raises a number of important themes about the artist's work in the first half of the $20^{\text {th }}$ century. Stērste's text, which is based on the principle of theatre in theatre, is a stylized form of commedia dell'arte, farce and balagan. The writer continues one of the most important early $20^{\text {th }}$-century symbolist traditions - selecting masks from Italian folk theatre - Harlequin, Pierrot and Columbine - and localizing the last two in her comedy.

In Elza Stērst's play Harlequin is not just a clown or a jester, he is:

1) the main actor Florestan in the theatrical performance Arlekina kāzas and Ziemas svètku tirdziña (In the Christmas Market);

2) a theatrical symbol, that is, a theatrical mask in real life or in Florestan's life;

3) a human double identity - a demonic side;

4) a vision of the infernal type or Mephistopheles.

Harlequin in Stērste's works first appears in the collection of poems Eizebijs un Florestāns (Eizebijs and Florestans, 1921). In the theatre Harlequin's mask has a long history. Some say it comes from the medieval mysteries, where Harlequin was the devil who tormented sinners in hell. The essayist, literary and theatre critic Jan Kott (1914-2001) in his study The Theater of Essence (1984) writes that Harlequin is the only commedia dell'arte hero who can simultaneously be both witty and happy and sad and simple at the same time. (Kott 1984: 16)

Amongst the latest commedia dell'arte examples in Latvian drama can be considered the author Austra Mètere-Ozola's (1907-1983) play Čiko (Chico,

9 Andrejs Stērste (1853-1921) - social activist, lawyer at the first period of Latvian awakening. 
SLŪKA

1943). This play was originally staged in Riga's Daile Theatre, but it was also popular among Latvian emigrants in Chicago in the 1950s.

Like in Damberg's and Stērste's texts, Mētere-Ozola's comedy is based in $20^{\text {th }}$-century Italy. The plot is based on the story of human relationships, love and everyday life. The play is constructed on two-levels, showing the masters' and thir servants' life. Like commedia dell'arte masks, in Mēteres-Ozola's play $\check{C}_{i k o^{10}}$ the servants have a decisive role in the progression of the plot - firstly they are doing everything that complicates the plot, but finally everything is successfully resolved.

One of Mētere-Ozola's characters is a middle-age woman, Aunt OrsolaLolu, who hates all women. She is raising two nephews, Paolo and Giovanni, and behaves very oppressively towards them. She can be compared with the reverse of the commedia dell'arte mask Pantalone, because she is colorful, domineering, cunning and at the same time a silly woman. If we analyze the text, we see two pairs of lovers - Paolo and Angelica, Giovanni and Simoneta, as well as the traditional triangular relationship (Harlequin-ColumbinePierrot) among the servants.

In Latvian drama one of the significant figures in this genre is the writer Valdemārs Dambergs (1886-1960). Dambergs's plays are little studied and analyzed because his comedies differ from those of other contemporary Latvian writers, for example, Andrejs Upits (1877-1970), Rainis (1865-1929) and Eduards Vulfs (1886-1919). In Damberg's plays there is neither a deep social, psychological or philosophical context and subtext nor profound symbols and other elements. However Dambergs's experiments with drama in the 1920s and 30s in relatively conservative Latvian drama had a considerable influence. Dambergs tried to create modernist contemporary plays with some classic Italian commedia dell'arte elements.

Dambergs's stylization techniques in the comedy Neticīga Kolombine (The Infidel Columbine, 1926) in some aspects are in tune with modernist playwrights such as Schnitzler, Blok and Lorca. In these authors' plays we find non-psychologically motivated people, with artificial lives - they are like puppets, living in a balagan-like world; they are unable to distinguish their theatre role from their personal life. These authors' plays present the reader (spectator) with the modern artist's favorite construction of the love triangle between three different types of individuals - Columbine (Dambergs Kolombine), Harlequin (Leo) and Pjero (Gralts) - new representations of the socialization process.

10 In Mētere-Ozola's play, Chico is a parrots' name, like in the American movie character, the clown Chico Marx (Green, Swan 1993: 11). 
Stylization of Commedia dell'arte in Latvian and Foreign Modernist Drama and Theatre

Eduards Smilgis experiences with the commedia dell'arte technique

Dambergs's work in the Jelgava Theatre (1936 to 1940 and 1941 to 1944) and his short monograph Karlo Goldoni komèdija 'Melis' Jelgavas teātrī (Carlo Goldoni's Comedy 'The Liar' in the Jelgava Theatre, 1940) is important. In this book, Dambergs writes that Latvian theatre performances had been long dominated by realistic, naturalistic and psychological depiction of life. Only Eduards Smilggis (1886-1966), the director and founder of the Latvian Dailes Theatre (Dailes teātris) - created and showed nonrealistic theatre on the stage.

Smilgigis opposed the contemporary literary and philosophical traditions of theatre; he produced classical plays and experimented with the style of the Italian masque comedies and the aesthetics of Asian and other theatres, thus creating splendid theatrical visions and worlds. (Zeltina 2012: 18)

Until the Second World War, Smilggis's Daile Theatre productions were not linked by direct realistic depictions of the aesthetic revelation (that were especially popular in the Latvian theatre during the first decade of the $20^{\text {th }}$ century). One of the Daile Theatre's main concepts was that theatre is not an exact mirror of life so therefore actors need not imitate life. Smilgis's modernist artistic experiments were closely related to stylization and theatricalization techniques.

Smilgigis restored theatrical theatre in his productions. With the Daile Theatre theorist and stage designer Jānis Muncis (1886-1955), Smilýgis produced contemporary plays that mirrored the European and Russian theatre directors' experience in the first decade of the $20^{\text {th }}$ century. For example, directors like Jacque Copeau in France; Max Reinhardt in Germany; Alexander Tairov and Vsevolod Meyerhold in Russia. These European directors represented the theatricalization technique in their theatre productions. Smilgis was interested in their experience. It was not a realistic school tradition, but a stylization, the modern artistic synthesis principle. For example, the first such attempt to show theatricalization was Rūdolfs Blaumanis' realistic comedy Skroderdienas Silmačos (Tailors' Days in Silmači, 1902) that in 1923 was produced on the Dailes Theatre stage like commedia dell'arte and was dubbed as a revolution in the Latvian theatre tradition.

Smilgis came to the Latvian theatre with a new claim that the theatre was a sovereign state having its own artistic truth, the theatre was not going to strive for imitation and the playwrights' work can only serve as a new pretext for new 
SLŪKA

truths. For example, in the Latvian writer Rainis's Spēlēju, dancoju (Played, Danced, 1926) Devil's characters were dressed in tail-coats and tuxedos, evening dresses and hell was shown as a revelry specific to the $20^{\text {th }}$ century.

\title{
End of the period of Modernism
}

Modernists seek new means of expression and form, and delve deeper into subjective feelings, which reflect the $20^{\text {th }}$ century's sharp contradictions. For them realistic ways do not seem so expressive or obsolete. Realism does not fully reproduce the human soul or the fragmented state of consciousness. Besides new forms of expression and innovative ways, Modernists show in their work that recourse to primary sources (such as the gross theatrical forms) and stylization or restoration allows art to be renovated and encoded in new, contemporary philosophical and aesthetic concepts. Commedia dell'arte stylization is one of the modernist art - theatricalization - features.

The socio-political events in states that after the Second World War were part of the USSR, including Latvia ${ }^{11}$, later contributed to the formation of Soviet Socialist realism in art. It was an ideological direction that very quickly became a peculiar religion - a socialist religion, offering specific forms of drama, new hero types, as well as a new 'non-confliction' attitude towards reality. That is why Modernism in Latvian drama can only be seen before the Second World War.

After the USSR collapsed (at the beginning of the 1990s) new art forms in Latvian theatre and drama - Postmodern Art - slowly arose. In the European postmodernism that emerged in the second half of the $20^{\text {th }}$ century, theatricalization and stylization in various forms constitute an important method. A peculiar culmination of stylization can be seen in the postmodern period with the emergence of the so-called reproductions of reproductions.

\author{
Viktorija Slūka \\ viktorija.lv@inbox.lv \\ Pamatskola „Rīdze“ \\ K.Valdemāra iela 2 \\ LV-1010 Rìga \\ LATVIJA
}

${ }^{11}$ Latvian exile literature and theatre developed in other ways. 
Stylization of Commedia dell'arte in Latvian and Foreign Modernist Drama and Theatre

\section{Bibliography}

Berghaus, G. 2005. Theatre, Performance, and The Historical Avant-Garde. New York: Palgrave Macmillan, 1-54.

Bradbury, M., McFarlane, J. 1991. Modernism. London: Penguin.

Brockett, O. G., Hildy, F. J. 1999. History of the Theatre. Eighth edition. Boston, MA: Allyn and Bacon, 143-149.

Clayton, J. D. 1993. Pierrot in Petrograd. The Commedia dell'Arte / Balagan in TwentiethCentury Russian Theatre and Drama. Montreal: McGill-Queen's University Press, 3-43, 232.

Dambergs, V. 1940. Karlo Goldoni komēdija "Melis" Jelgavas teātrī. Rīga: Zelta Ābele.

Dambergs, V. 1936. Neticīgā Kolombinne. Rīga: Grāmatu apgādniecība A. Gulbis.

Fava, A. 2007. The Comic Mask in the Commedia dell'Arte. Canada: Northwestern University Press.

Gay, P. 2009. Modernism. London: Vintage Books, 1-30.

Green M., Swan, J. 1993. The Triumph of Pierrot. The Commedia dell'Arte and Modern Imagination. USA: The Pennsylvania State University Press, 1-53, 233-260.

Kott, J. 1984. The Theater of Essence. Evanston, IL: Northwestern University Press, 11-30.

Kundziņš, K. 1968. Latviešu teātra vēsture. I sējums. Rīga: Liesma.

Mētere-Ozola, A. 1943. Čiko. Rīga: T.O. Šteinberga apgāds.

Pavis, P. 2003. Slovar' teatra. Moskva: GITIS. = Павис, П. 2003. Словарь театра. Москва: ГИТИС, 154-155, 331-332.

Radzobe, S. 2002. 20. gadsimta teātra režija pasaulē un Latvijā. Rīga: Jumava, 8-153.

Rudlin, J. 1994. Commedia dell'Arte: An Actor's Handbook. London and New York: Routledge.

Stērste, E. 1938. Arlekīna kāzas. Rīga: Grāmatu apgādniecība A.Gulbis.

Stērste, E. 1985. Atmiṇu raksti. - Karogs, Nr.2, 158-168, Nr.3, 150-157.

Stērste, E. 1921. Eizebijs un Florestāns. Rīga: LETA.

Whitworth, M. H., ed. 2007. Modernism. Oxford: Blackwell Publishing, 2-41.

Zeltina, G., ed. 2012. Theatre in Latvia. Riga: University of Latvia, Institute of Literature, Folklore and Art, 7-73. 